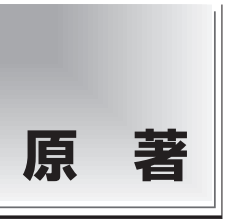

論文受付

2017 年 3 月 14 日

論文受理

2019 年 2 月 27 日

Code Nos. 1060

1061

1080

\section{相関分析を用いた医療機器および 病院情報システム導入時における重要因子の検討}

\author{
谷 祐児 $^{1}$ 藤原健祐 $^{2}$ 鈴木哲平 $^{2} \quad$ 小笠原克彦 ${ }^{2}$
}

${ }^{1}$ 旭川医科大学旭川医科大学病院経営企画部

2 北海道大学大学院保健科学研究院

\section{緒 言}

医療機関における設備投資は一般的に高額なものが 多い, 特に画像診断装置 (機器), 関連情報 (information technology: IT) システムや病院情報システム (hospital information system: HIS) は時に大きな設備 投資を必要とするものである，昨今では，業務改善や 業務効率化を目的とした IT 設備の導入が増加し，そ の中でも代表的な電子カルテシステムやオーダリング システム, picture archiving and communication sys- tems (PACS) といった医療情報システムあるいは HIS の普及は目覚ましく ${ }^{11}$, 各医療機関においてもその導 入機会が多くなってきている2．以前は，大規模病院 に扔ける導入が主流であったが，200 床未満規模のい わゆる中小規模病院に扮いても増加傾向となってき た。併せて，医療技術の進歩により画像診断機器も 年々その機能を拡充し, 診療への需要からより高度な 医療機器の導入が進んでいる.

これら機器や HIS の導入プロセスとしては,メーカ

\title{
Examination of the Important Factor during Implementation of the Medical Equipment and Hospital Information System Using the Correlation Analysis
}

\author{
Yuji Tani, ${ }^{*}$ Kensuke Fujiwara, ${ }^{2}$ Teppei Suzuki, ${ }^{2}$ and Katsuhiko Ogasawara ${ }^{2}$ \\ ${ }^{1}$ Department of Medical Informatics and Hospital Management, Asahikawa Medical University Hospital, Asahikawa Medical \\ University \\ ${ }^{2}$ Graduate School of Health Sciences, Hokkaido University
}

Received March 14, 2017; Revision accepted February 27, 2019

Code Nos. 1060, 1061, 1080

\section{Summary}

During medical equipment and hospital information system implementation in small- and medium-sized hospitals, the system introduction often advances after system selection by the management. However, in reality, the requirements of the systems between the management and staff layers were different. Therefore, the system did not often satisfy staff demands, resulting in increased dissatisfaction of the staff for the system. It was important to consider the staff's opinion at the selection of the system manufacturer, vendor, and system to resolve their dissatisfaction for a system. In this study, we let the staff decrease these dissatisfactions in selecting a system manufacturer, vendor, and a system at the system implementation. Therefore, we consider a more useful system implementation method through the staff' $\mathrm{s}$ motivation building by the questionnaire result analysis. The questionnaire was carried out after each event in relation to system implementation. The enforcement of event for system implementation was useful for the staff's motivation building, because we can consider the staff's opinion with staff understanding. During system implementation, it was important and/or necessary for building the staff's motivation for the success of the system implementation and to utilize it after the implementation.

Key words: medical equipment, hospital information system, motivation, motivation-hygiene theory, Maslow's hierarchy of needs

*Proceeding author 
やベンダおよび機器や HIS 自体の選定, それらの仕様 決定，そして導入といった流れが考えられる。しか し, 実際に各医療機関において導入する場合の選定プ ロセスは多種多様であるが，その規模によりプロセス が変わることが多い，大規模病院などの場合は，ワー キンググループ(working group: WG)などを適宜設置 し関係部署により各項目の仕様案を策定し, それらを まとめた要求仕様書を基にした競争入札の実施など, 比較的オープンな環境で選定が行われることが多い. 一方, 中小規模病院においては, 理事長や院長といっ たいわゆるマネジメント層により, 機器や HIS の仕様 や選定がトップダウンにより決定される事案が多くみ られる。これにより，実際にそれらを日久使用する現 場スタッフの意見は, 仕様や選定といった機器や HIS の導入プロセス時には反映されにくい仕組みとなって おり, 導入プロセス自体が大規模病院のそれとは大き く異なっているのが現状である.

社団法人全日本病院協会による, 比較的病院規模が 小さい会員病院および 400 床以上の非会員病院を対象 とした情報システム導入・活用状況アンケート調査に 扔いて, 電子カルテ, オーダリングシステム, 各部門

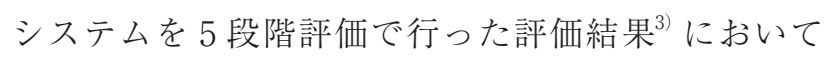
は, 大規模病院と比較して中小規模病院における HIS 導入後の評価結果が低いという結果が示されている. これは, 大規模病院と比較して中小規模病院において は, 機器や HIS 選定者であるマネジメント層と利用者 である現場層とでは, それらへ期待する機能や導入効 果などといった意識の相違が大きくなることに起因す るものであることが考えられる。このギャップを解消 させ導入後の評価を向上させるためには, 現場層の機 器や HIS への期待を裏切らないことが重要であり, そ のためには導入するメーカやベンダを始め, 機器や HIS 選定当初より現場スタッフの意見を反映すること が有用であると考えられる。しかし，実際にそれらを 実行するには，現場スタッフへのヒアリングや意見集 約のための費用のみならず，時間や手間といった総合 的なコストの増加が容易に予想される。このため, 実 際の導入に打けるシチュエーションでは敬遠されるこ とが少なくない.

本研究では, 対象病院における機器㧍よびHIS 導入 を前提としたメーカおよびベンダや機器および HIS 自体の選定において，実際にそれらを利用する立場で ある現場スタッフのニーズを踏まえた機器および HIS 導入を目標として，更に導入後の評価の向上や不満の 解消を目的とし, 選定プロセスに現場スタッフの参画 を試行した。その導入プロセスにおいて, 各種イベン
トを通して情報提供や意見の集約を行い，そのイベン 卜実施後に行ったアンケート調査結果に対する相関分 析から現場のモチベーションの醸成の動向を可視化す ることで, システム導入に対する重要因子について検 討した。

\section{1. 方 法}

対象病院に㧍ける HIS 導入に向けて, まずプロジェ クトチーム (project team: PT)を 7 名で発足させた. PTメンバーは, 医療情報室室長を委員長とし, 院長, 看護部長, 事務部 2 名, 看護部 1 名, リハビリテー ション部 1 名で構成した. PT による数回のミーティ ングを経て, PTメンバーにより, 全職員を対象とし たプロジェクト内容を含めた医療情報システムに関す る説明会を行った。 その後, 医療機器メーカや HIS ゙ ンダおよび機器や HIS 選定, 導入にむけたWG を発 足させた. WGは, 外来抢よび入院の 2 チームを, 各 チーム 10 名程度で編成した，メンバーは，外来扔よ び入院の診療プロセスに関係する部署の役職者を除く 現場担当者を各部署からの選出によりチームを構成し た。な扮, 外来関連部署は, 医局, 事務部, 看護部外 来担当, 放射線科, 薬剂部, 入院関連部署は, 医局, 事務部, 看護部病棟担当, 放射線科, 薬剂部, 栄養科 とした.PT主導の下に, 他病院のシステム見学会,

医療情報システム関連勉強会等をはじめとした全職員 (理事を除く 86 名) および WG メンバーに向けた情報 提供を実施し, 各イベント終了時にはアンケート調査 を実施した。

今回実施したイベント内容, 開催時期, 参加人数を Table 1 に示す.

今回実施したイベントは以下のと㧍りである。（） 内は参加人数を示す.

(1) IT 推進プロジェクト全体説明会 (74 名)

(2)第 1 回 HIS 勉強会 (45 名)

(3)第 2 回 HIS 勉強会・メーカによる HIS デモンス トレーション $(16$ 名 $)$

(4)第 2 回他病院見学会 (10 名)

(5)ディジタル X 線 (digital radiology: DR) 装置・外科 用イメージ装置説明会 (11 名)

(6)画像参照用高解像度モ二夕装置見学会 (23 名)

各イベント後に実施したアンケートは, 質問が 6 項 目の簡便なアンケート調査とし, 測定は Likert 法に よる 5 段階評価法を使用し, 各項目ごとにその項目の 度合いに応じて 1 点から 5 点とした。 なお, Likert法 は社会科学分野の調查では多用される心理的順序尺度 
Table 1 The list of implementation events, schedule and the number of participants

\begin{tabular}{|c|c|c|c|c|c|c|c|c|}
\hline Event & Mar & Apr & May & Jun & Jul & Aug & Sep & Oct \\
\hline Briefing (IT promotion project) & 74 & & & & & & & \\
\hline Seminar of HIS (1st) & & & 45 & & & & & \\
\hline Seminar of HIS (2nd) and demonstation of system & & & 16 & & & & & \\
\hline Site visit of other hospital (2nd) & & & & & & 10 & & \\
\hline Briefing (DR system and surgical imaging system) & & & & & & & 11 & \\
\hline Observation (Monitor system) & & & & & & & & 23 \\
\hline
\end{tabular}

による測定方法であり ${ }^{4)}$ ，今回はスケールを用い選択 肢間の心理的距離を等しくするように努め, 間隔尺度 として分析を行っている ${ }^{5,6)}$. その調查結果から, 参加 者の説明会·見学会·勉強会など各イベントに対する,

(1)プロジェクト関連当該イベントの必要度

(2)プロジェクト関連当該イベントの参加満足度

(3)プロジェクト関連当該イベントに対する今後の参 加意欲

の 3 項目を要因として抽出し, これにフリーコメント を加えて抽出し分析対象とした。

\section{1-1 アンケート調査結果推移 (時系列観察)}

アンケート調査結果より抽出した各要因(プロジェ クト関連当該イベントの必要度・プロジェクト関連当 該イベントの参加満足度 · プロジェクト関連当該イベ ントに対する今後の参加意欲) ごとに各イベントの結 果推移(時系列推移)を分析することにより，モチベー ションの動向を可視化した。

\section{1-2 WG メンバーの参加意欲に対する主観的評価}

隔週で開催された各 WG ミーティングにおける参 加メンバーの参加意欲を, オブザーバとして参加して いる PTメンバー 5 名がディスカッションにより主観 的に定性評価を行った。

\section{1-3 各要因間相関分析}

各イベント時における各要因間の相関係数を算出 し，その影響の大きさを比較した。

なお，アンケート調査実施にあたり本アンケートの 回答者には事前に回答の分析結果の研究での使用の旨 を説明したうえで回答を依頼し，アンケートは無記名 形式で行い個人情報を削除し個人を特定できない形へ 処理後に分析を行った。また，相関分析にはIBM 社 SPSS Ver.19を使用した。

本研究を実施するにあたり，当該施設には倫理委員
会が存在しないため同等の役割をもつ施設長から本研 究に対する承認を得た。

\section{2. 結 果}

各アンケートの回答数は以下のとおりである.

(1) IT 推進プロジェクト全体説明会……73

(2)第 1 回 HIS 勉強会 $\cdots \cdot \cdots 45$

(3)第 2 回 HIS 勉強会・メーカによる HIS デモンス トレーション ……16

(4)第 2 回他病院見学会……9

(5) DR 装置・外科用イメージ装置説明会 $\cdots \cdots \cdot 10$

(6)画像参照用高解像度モ二夕装置見学会……19

\section{2-1 アンケート調査結果推移(時系列観察)}

\section{2-1-1 プロジェクト関連イベントの必要度}

Figure 1 に，アンケート結果から抽出したプロジェ クト関連イベントの必要度の結果推移を示す。なお, グラフ左から右に向かって時間の経過を示している.

プロジェクト開始当初は，2 点，3点の低得点も 2〜3 割程度散見されたが，時間の経過とともに低得点 が減少した。イベント開催 4 回目以降は 4 点, 5 点の 高得点が占める割合が増え, そのほとんどが高得点と なっていったことから，プロジェクト開始当初はプロ ジェクト関連イベントの必要度はあまり感じていな かったものの，時間の経過とともにイベントに対する 必要度が高まっていったものと考えられる。

\section{2-1-2 プロジェクト関連イベントの満足度}

Figure 2 に，アンケート結果から抽出したプロジェ クト関連イベントの参加満足度の結果推移を示す。な お，(1)必要度と同様にグラフ左から右に向かって時間 の経過を示している。

プロジェクト開始当初は，3 点が半数程度を占め, 2 点といった低得点も散見されていたが，イベント開催 4 回目以降は 2 点や 3 点といった低得点の割合が減少 し, 4 点, 5 点といった高得点が占める割合が多くなっ た。このことから，プロジェクト開始当初イベント開 


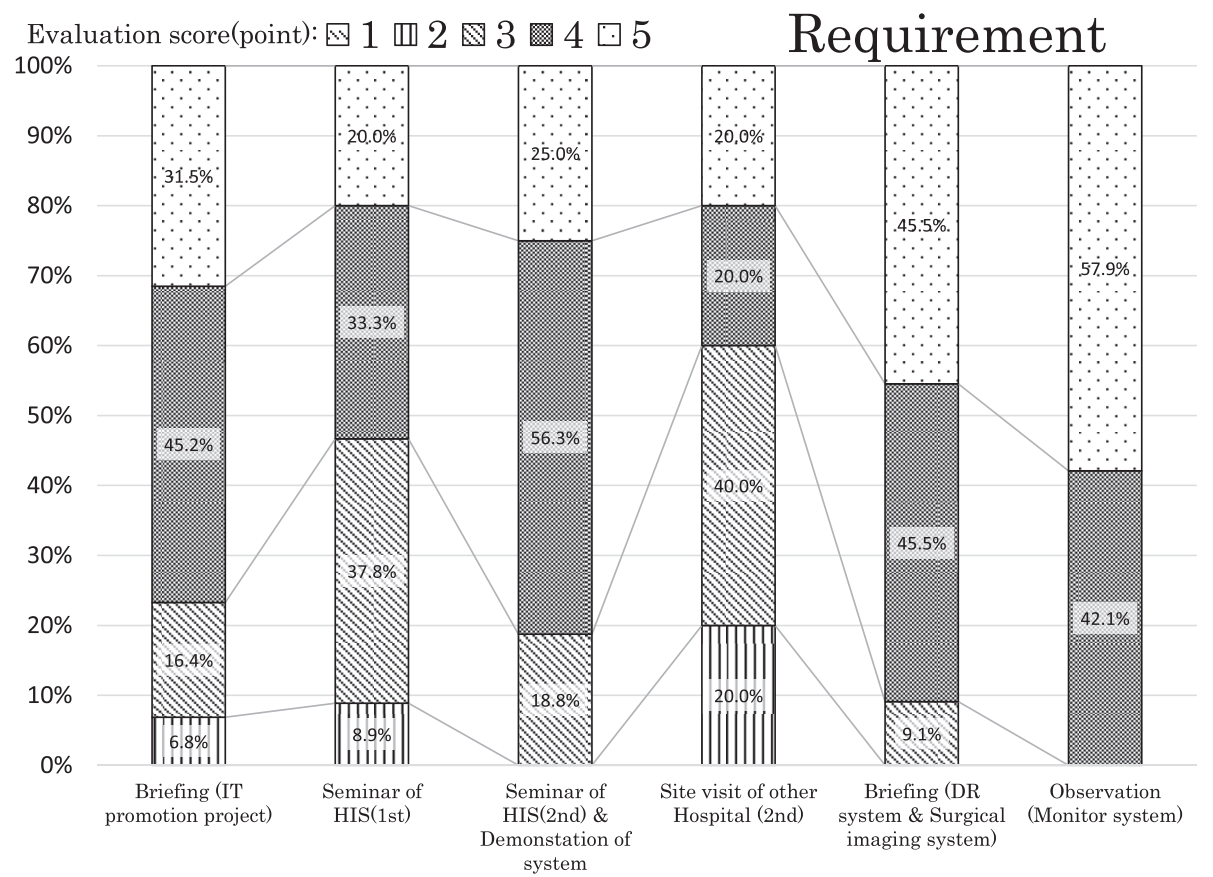

Fig. 1 The changes in the results of requirement of event for implementation system.

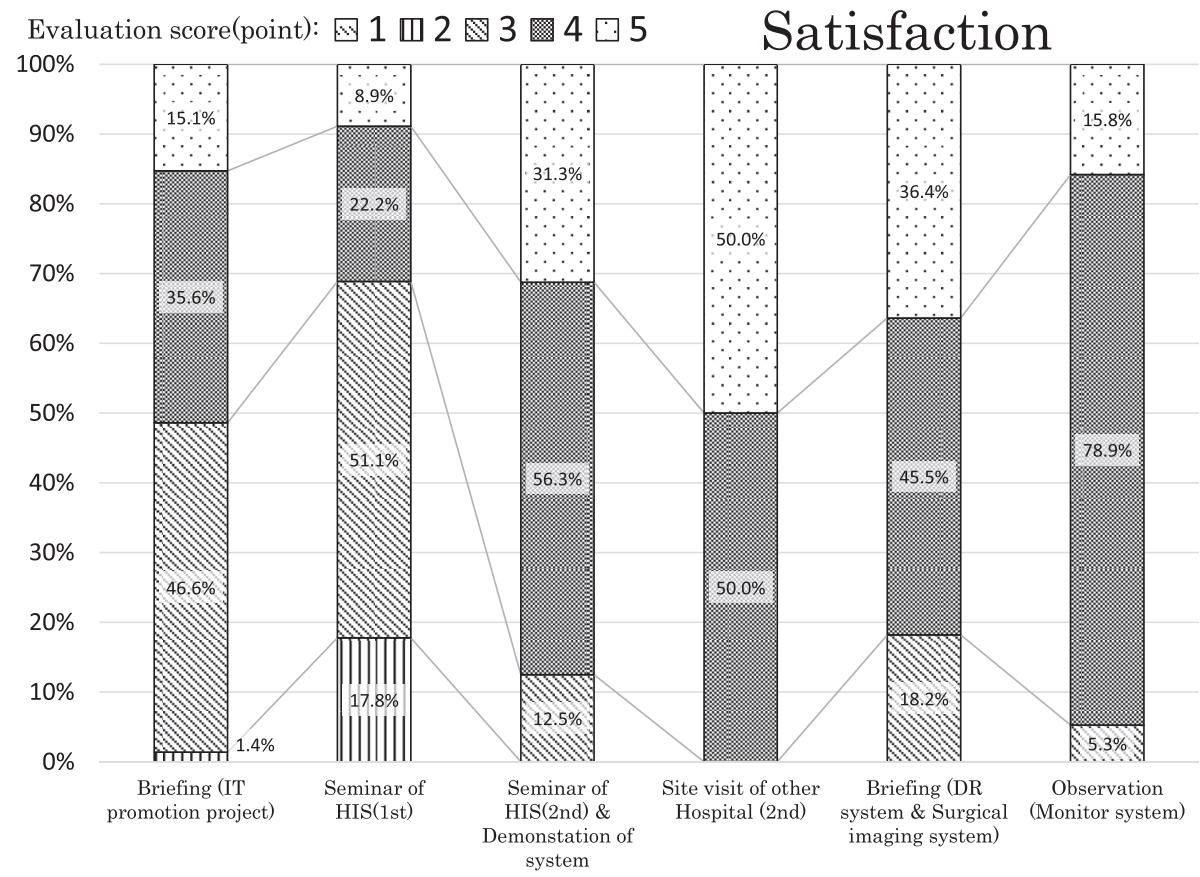

Fig. 2 The changes in the results of satisfaction of event for implementation system.

催 2 回目までは, プロジェクト関連のイベントに対す る満足度は 2 点が散見されるなどあまり高くなかった が, 時間の経過とともにイベント開催 4 回目以降では 3 点以上が増加し満足度の向上が認められた。

\section{2-1-3 プロジェクト関連イベントに対する今後の参 加意欲}

Figure 3 に,アンケート結果から抽出したプロジェ
クト関連イベントに対する今後の参加意欲の結果推移 を示す。なお，(1)必要度と同様にグラフ左から右に向 かって時間の経過を示している.

2.1.1プロジェクト関連イベントの必要度と同様に, プロジェクト開始当初は 2 点や 3 点といった低得点が 散見されているが, 時間の経過とともに低得点が減少 し, イベント開催 3 回目以降では 4 点, 5 点といった 


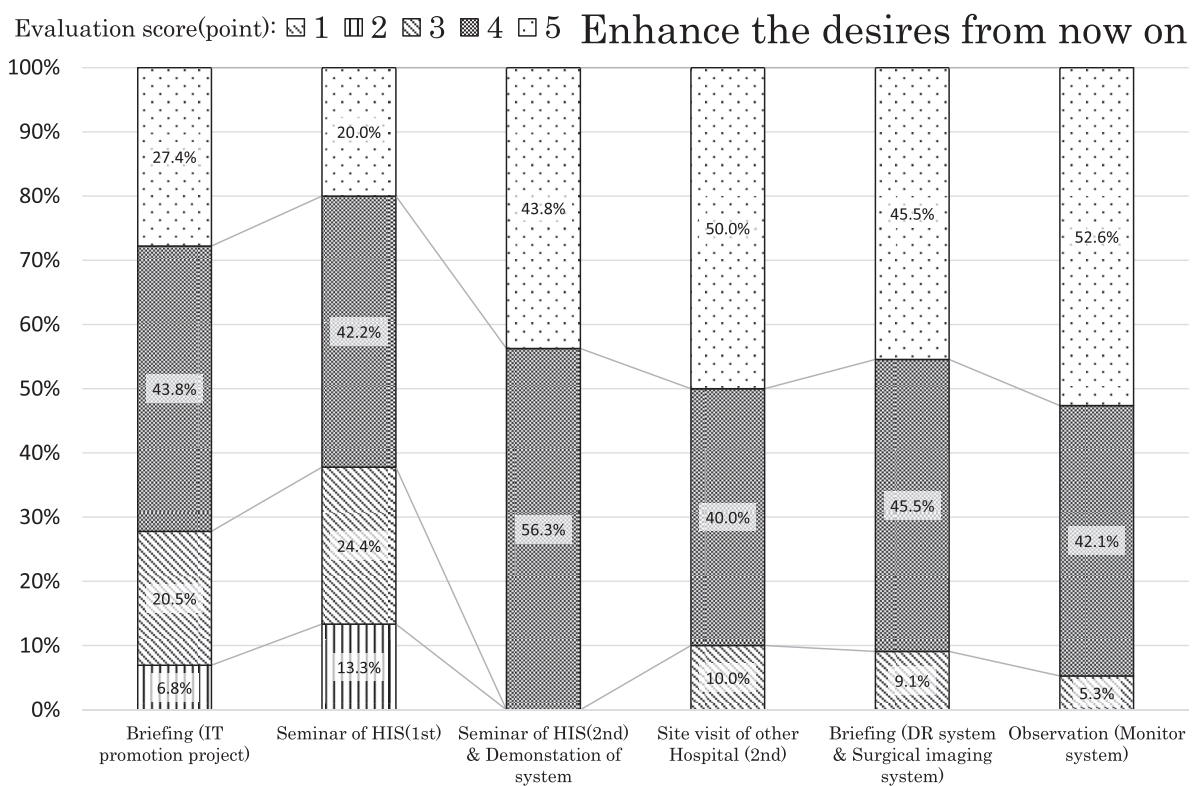

Fig. 3 The changes in the results of desires for participation of event in the future for implementation system.

高得点が占める割合が多くなった。このことから，プ ロジェクト開始当初はプロジェクト関連の今後のイベ ントに対する参加意欲は低かったものの, 時間の経過 とともにイベント開催 3 回目以降は参加意欲が高まっ ていったものと考えられる.

\section{2-1-4 プロジェクト関連イベントに対するフリーコ} メント

フリーコメントの一部抜粋を以下に示す。なお，コ メント記載率は平均 $22.7 \%$ であった。

【フリーコメント】

>主旨がよく理解できたのでよい機会だったと思 います。

>初めての試みなのでしっかり勉強してよいもの にしたいです。

> 理解力のない私には何度でもわかるまで聞きた いので聞いたら説明宜しくお願いします。説明 会ありがとうございました。

>必要の有無にかかわらず, 知るということはよ いことであると思います。ありがとうございま した。

参加者のフリーコメントでは，上記に示すような各 イベントに対する肯定的な意見が多く，否定的な意見 はほとんどみられない結果となった。

\section{2-2 WG メンバーの参加意欲に対する主観的評価}

今回試行した一連の手法は, 対象病院では過去に全
く経験がなかったため，WG 活動開始直後は，戸惑い からか各メンバーとも積極性はあまりみられず，WG ミーティングにおいても各メンバーからの発言や意見 はあまり出なかった。これらのことより, $\mathrm{PT}$ ×ン バーはWGメンバーに対し受動的な行動が多い印象 を受けていた。

しかし，プロジェクト関連イベントの回数を重ねる につれ，積極的な意見や発言が増加するなど能動的な 行動が増え積極性が向上したとの意見が大多数で あった。

\section{2-3 各要因間の相関分析結果}

Figure 4 に各イベント時における必要度・参加満足 度・今後の参加意欲のクロス表を示す。なお, 各クロ ス表の行および列は各要因での得点を示し，表内の数 字はそれぞれの人数を示す。

また，各イベント時における各要因間の相関分析を Table 2 に示す.

各イベントにより，相関分析の結果は多少異なる が，プロジェクト関連当該イベントの必要度と参加意 欲間，およびプロジェクト関連当該イベントの満足度 と参加意欲間で有意に高い相関が認められた。しか し，プロジェクト関連当該イベントの必要度と満足度 間では一部有意な相関がみられるものの, その相関は 中程度〜弱いものであった。 


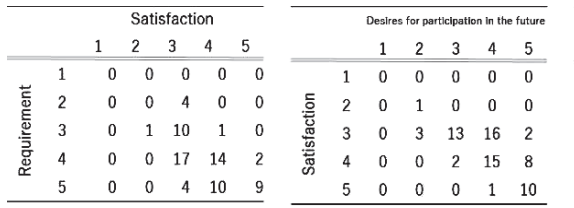

(a) Briefing (IT promotion project)
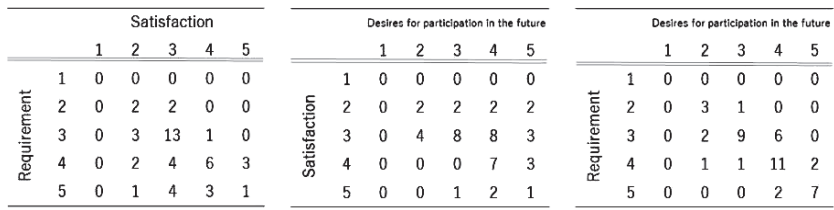

(b) Seminar of HIS (1st)

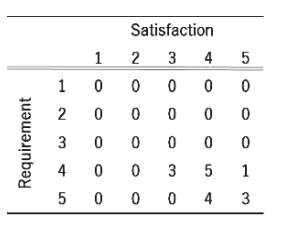

(c) Seminar of HIS (2nd) and demonstration of system
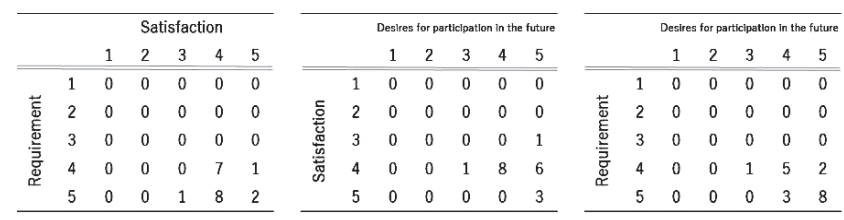

(d) Site visit of other hospital (2nd)

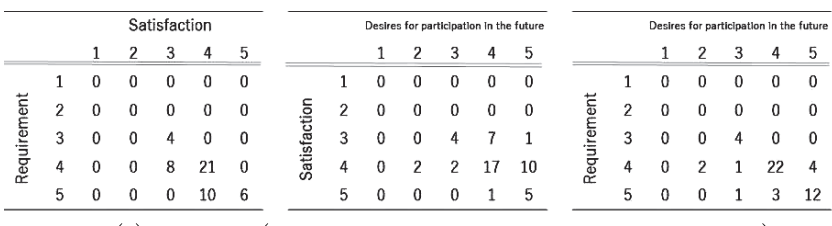

(e) Briefing (DR system and surgical imaging system)

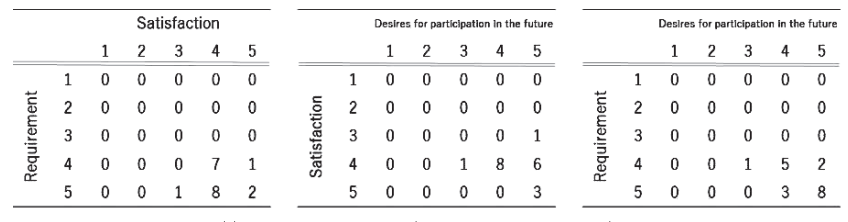

(f) Observation (Monitor system)

Fig. 4 The cross-tabulation table in each event.

Table 2 The results of correlation analysis for each item

\begin{tabular}{lccc}
\hline \hline & Requirement/satisfaction & $\begin{array}{c}\text { Requirement/desires for } \\
\text { participation in the future }\end{array}$ & $\begin{array}{c}\text { Satisfaction/desires for } \\
\text { participation in the future }\end{array}$ \\
\hline Observation (Moniter system) & $0.547^{* *}$ & $0.781^{* *}$ & $0.662^{* *}$ \\
Briefing (DR system \& surgical imaging system) & 0.327 & 0.093 & $0.689^{*}$ \\
Site visit of other hospital (2nd) & 0.098 & $0.736^{*}$ & 0.302 \\
Seminar of HIS (2nd) and demonstation of system & 0.490 & 0.335 & $0.720^{* *}$ \\
Seminar of HIS (1st) & $0.399^{* *}$ & $0.765^{* *}$ & 0.285 \\
Briefing (IT promotion project) & $0.574^{* *}$ & $0.781^{* *}$ & $0.662^{* *}$ \\
\hline
\end{tabular}
${ }^{*} \mathrm{p}<0.05$

$\mathrm{p}<0.01$

\section{3. 考察}

\section{3-1 モチベーションについて}

本研究では, 相関分析を用いて医療機器およびシス テム導入時における重要因子の検討を行った。モチ ベーションとは，一般的に多用される言葉であるが, 人が一定の方向に向かって行動しそれを維持する働き として定義されており，日本語では「動機づけ」ある いは「やる気」と表現される。また，モチベーション 理論においては個人レベルの組織行動論の中心となる ものであり，「目標達成のための高レベルの努力を行 おうとする個人の意思」と定義されている7). このモ チベーションは, 大きく分けて, (1)動因 (ドライブ)と, (2)誘因(インセンティブ)の二つの要因により生じると いわれており，動因は自身内部からの欲求により行動 を起こす内部的な力で, 誘因は外部の目標などにより
行動を起こす外部的な力である ${ }^{8,9)}$. このモチベー ションがこれら二つの要因から生じるということは, マーズローの欲求階層説 (hierarchy of needs theory), あるいはハーズバーグの動機づけ衛生理論 (motivation hygiene theory)において説明されている ${ }^{10,11)}$.

欲求階層説は, 心理学者であるマーズローが 1943 年に提唱したもので, (1)人間行動は欲求の満足化行動 である, (2)欲求の五つの欲求次元が最低次から最高次 へと順に階層化しているという二つの仮定から成り 立っている。五つの欲求次元とは, (1)生理的欲求, (2) 安全でありたい欲求, (3)㷌属・愛情を得たい欲求, (4) 尊敬を得たい欲求, (5)自己実現をしたい欲求でありこ れらが階層化しており，この欲求を順次満たすことが 行動の源泉であるという理論である ${ }^{10,11)}$. 一方, 動機 づけ・衛生理論は, ハーズバーグが 1959 年に提唱した 
モチベーションを高めるのに寄与する「動機づけ要 因」と，不備だと不満の源泉となるが整備されている と不満の発生を防止可能な「衛生要因」の 2 種類の要 因がモチベーションや職務満足の原因となり両者は互 いに独立であるという理論である ${ }^{10,11)}$ ，この「動機づ け要因」には, (1)仕事の達成, (2)承認, (3)仕事自体, (4)責任など,「衛生要因」は仕事の環境要因ともいわ れ，(1)会社の方針と管理方法，(2)監督方法，(3)人間関 係，(4)作業条件，(5)給与などが含まれる。これらは, モチベーションの古典的理論に含まれる ${ }^{10,11}$. 今回の プロジェクトに向けた各イベントによる HIS に関す る情報提供や選定プロセスの参画によって, 自らシス テム導入や運用プロジェクトに対して積極的に関与す ることが可能となり, 前述の欲求に打ける(3)から(5)層 の欲求を満たす行動を起こすことでモチベーションが 醸成される。また, それらの行動が動機づけ要因の各 要因のうち, その置かれた状況による複数の要因が満 たされることによりモチベーションが釀成され, 更 に，今回のようなプロジェクトは現場などへの権限移 譲など環境要因を整備することを前提としているた め, 衛生要因のうちの(1)から(4)が整備されることによ り各要因が整備されることで, 不満が解消されモチ ベーション醸成へとつながっていくと考えられる.

また，さまざまなプロジェクトを遂行していくにあ たり, プロジェクトメンバーのモチベーションは, 当 該プロジェクトの成否に大きな影響を与えることはよ く知られている ${ }^{12 \sim 17)}$ 。これは病院組織におけるプロ ジェクトに抏いても例外ではなく, 特に今回着目して いる医療情報システムをはじめとした医療機関におけ る各種機器や HIS の導入プロジェクトにおいては, そ のプロジェクトに関連するメンバーや，それらのシス テムを実際に使用していかなければならない現場層の 職員のモチベーションの醇成や向上, 維持がそのプロ ジェクトの成否に大きく影響を及ぼす。また, 導入し たシステムの活用度にも大きく影響すると考えられ る.これは, このようなプロジェクトの目的は, 機器 や HIS を導入すること自体ではなく, 導入によりいか に業務効率を向上させるかである，現場層の職員が自 分たちで選定・導入したものを活用することは自然な 流れである。このため, プロジェクトを遂行していく にあたりプロジェクト構成要員や関連職員のモチベー ションを醸成することは非常に重要であり, これらを 上手く醸成することによりプロジェクトを成功に導い ていくことができると考えられる.

ただし，実際の業務に扔けるシステム導入では，当 該システムを利用する職員が複数の部署にまたがるこ
とも少なくない.このような場合には, 部署間の利害 関係といった，モチベーションとは異なった要因の影 響が考えられる。このため, 実際の業務においては, さまざまな視点での検討が必要になると考えられる.

\section{3-2 モチベーション醸成のスキーム}

今回実施した機器および HIS 導入に向けた各イべ ント (システム説明会・見学会・勉強会) は, その導入 にあたりメーカやベンダ及び機器抒よび HIS 自体の 選定時より現場スタッフの参加を促すことにより，現 場スタッフに, 検討に必要な情報や意志決定にかかわ る意見を吸い上げることを可能にする。これは，現場 スタッフに対してその存在感を認めることにつなが り, 現場スタッフの「存在に対する肯定的なストロー ク」と考えられる.この「存在に対する肯定的なス卜 ローク」により効果を発揮するとされている「行動に 対する肯定的アプローチ」がモチベーションを醇成す る要因となると考えられ，ハーズバーグの動機づけ衛 生理論においてもこれらが説明されている ${ }^{10,11)}$. ここ で，ストロークとは交流分析 (transactional analysis: TA) と神経言語プログラム (neuro linguistic programming: NLP)を元に考案された breaking the communication barrier (BCB)に拈ける人と人とのかかわり方 を表したものであり．モチベーションのキーと説明さ れている ${ }^{18)}$.

一方，これらの「存在に対する肯定的なストローク」 および「行動に対する肯定的なストローク」が否定さ れることによりそのストロークが阻害され，それによ り「行動に対する否定的ストローク」拉よび「存在に 対する否定的ストローク」が発現することでやる気が 減少し，これがモチベーション低下をきたしてしまう と考えられる ${ }^{18)}$.

結果 2-1-1 2-1-3 に抏いて各イベントでのアンケー 卜結果に扔ける必要度・満足度・参加意欲の点数が, イベント開催 3 回目あるいは 4 回目以降でみられた時 系列的に高得点評価へと推移していったことは, 各イ ベントの開催により参加者の本プロジェクトへの理解 が進むことで各イベントの必要性や満足度, 参加意欲 が向上したと考えられる。また, 結果 2-2でみられた WG での参加メンバーの参加意欲も説明会や情報発信 等といったイベントの参加回数を重㸚る度に向上して いったことは, 本プロジェクトの目的が WGメンバー それぞれの思考の中で明確化されたためと考えられ る. 以上のことは, 積極的なプロジェクトへの参加と も考えることができ，モチベーションの醸成であると 考えられた。結果 2-3 各要因間の相関に打いても, 必 
要度と参加意欲間, およびプロジェクト関連当該イベ ントの満足度と参加意欲間で有意に高い相関が認めら れた。これは, 各イベントの必要度が認知されると次 回以降のイベントに対する参加意欲が高まり，またイ ベントに対する満足度が高まると次回以降のイベント に対する参加意欲が高まるものと推測できる，以上の ことからも，関連イベントを継続的に実施していくこ とによりそれぞれの要因が関連して向上していると考 えることができる，一方で，プロジェクト関連当該イ ベントの必要度と満足度間では, 必ずしも相関が高く なかった，これは，そもそも双方とも当初より4から 5 の比較的高い水準で推移して抢り, また, 満足度は 個々人により指標が異なり，意識や知識レベルが異な る参加者すべてに対して満足感を感じさせるイベント を一度で実施することは困難であることが考えられ た。このため, 意識や知識レベルに合わせて複数回実 施することの必要性も考えられた。これらは, イベン トを開催することにより「存在に対する肯定的なス卜 ローク」および「行動に対する肯定的なストローク」 が, 前述のようなスキームで参加者に対して形成され ることによりモチベーションの酹成に成功していった ものと考えられる。言い換えると，モチベーションを 醸成するためには，このようなイベントをはじめとし た「存在に対する肯定的なストローク」拈よび「行動 に対する肯定的なストローク」を与えるスキームを作 る必要性があると考えられる。

本研究の限界として，モチベーション自体を定量的 に測定するのが困難であるため, 定性的な判断になら ざるを得ない点が考えられる。このため, どうしても 測定者の判断にゆだねるところが大きくなることが考 えられる，今後は，この点を解消できるような代替指 標などを検討していきたいと考えている.

また, 本研究の今後として, 実際のシステム導入後 に職員に対してシステム仕様に対する満足度等の追跡 調査を行い, 当初からの現場レベルの参画やモチベー ションとの関係性から, 更なる重要因子の調査・検討
を行っていきたい.

\section{4. 結 語}

本研究では, 実際に当該システムを利用する立場で ある現場スタッフのニーズを踏まえた機器や HIS 導 入を目標として, メーカおよびベンダ，そしてそれら 自体の選定プロセスに現場スタッフの参画を試行し, その導入プロセスにおいて開催した各種イベント実施 後に行ったアンケート調查結果に対する相関分析から 現場のモチベーションの醸成の動向を可視化すること で, システム導入に対する重要因子について検討した。

その結果, イベント開催回数が重ねられるにつれ, プロジェクト内容の理解, イベントの必要性の認知や 参加満足度, 今後の意欲などが向上することが確認で き, これらは現場スタッフのモチベーション向上であ ると考えられた，このモチベーションの䁔成により， 実際のシステム導入時に拈いて, 現場スタッフにシス テムへの関与の当事者感を生むことで, よりシステム の活用が期待できる.

医療機関に扔ける医療機器や IT 設備, 医療情報シ ステムといった大きな設備投資を伴う機器や HIS 導 入において, 現場スタッフのモチベーションを向上さ せるための選定時からの参加, 導入プロジェクトへの 理解や目的の共有は重要因子の一つであり成功の必須 条件である、特に中小規模病院に扔いては, その影響 が大きく, そのためには, 説明会や勉強会といった各 種イベントを通じてシステム内容など必要な情報を提 供し, 併せて現場スタッフの意見を吸い上げることが 現場の当事者意識を生み，モチベーションを醸成する ことに対して有用であると考えられる。

なお, 本研究は平成 25 年度北海道放射線技術研究 助成金を受け実施し, 本研究の要旨は, 第 42 回日本放 射線技術学会秋季学術大会 (2014 年, 札幌)にて報告 した。

\section{参考文献}

1）厚生労働省. 第 3 回社会保障分野サブワーキンググルー プ及び医療機関等における個人情報保護のあり方に関す る検討会の合同開催。資料 2. 2012.

2）大江和彦. IT 投資の有効性の視点から. 病院 2010;69 (4): 269-274.

3）飯田修平, 永井 肇, 長谷川友紀. 病院情報システム導入 の手引き。東京：じほう, 2007.

4）栗原伸一. 入門統計学. 東京: オーム社, 2014.

5) 田部井明美. SPSS 完全活用法 共分散構造分析 (Amos)

によるアンケート処理 第 2 版. 東京: 東京図書, 2011.

6）脇田貴文. Likert 法における回答選択枝のレイアウトが 選択枝間の心理的距離に与える影響. 関西大学社会学部 紀要 2012; 43(2): 135-144.

7）金井壽宏, 高橋 潔. 組織行動の考え方. 東京: 東洋経済 新報社, 2004 .

8）中島義明, 繁柲算男, 箱田裕司編. 新 - 心理学の基礎知 識. 東京：有斐閣, 2005.

9）白佐俊憲, 竹田唯史. 教養の心理学. 東京 : 川島書店, 
1999.

10）榊原清則。経営学入門 (上). 東京：日本経済新聞社, 2002.

11）野中郁次郎。経営管理．東京：日本経済新聞社，1983.

12）井野川幸彦, 田端真由美, 平山敏弘. プロジェクトにおけ る要員育成とモチベーションの関係について．プロジェ クトマネジメント学会 2013 年度春季研究発表大会予稿 集. 2013: 112-115.

13）松本真治. PS 満足度に基づく小規模プロジェクトにおけ るモチベーションマネジメント。プロジェクトマネジメ ント学会 2004 年度春季研究発表大会予稿集. 2004: 189193.

14) Peterson TM. Motivation: How to increase project team performance. Project Management Journal 2007; 38(4): 60-69.
15) Schmid B, Adams J. Motivation in project management: The project manager's perspective. Project Management Journal 2008; 39(2): 60-71.

16) Katz R. The effects of group longevity on project communication and performance. Administrative Science Quarterly 1982; 27(1): 81-104.

17）谷 祐児，佐瀬雄治，小笠原克彦．中小規模病院における 病院情報システム選定・導入手法における考察〜現場モ チベーション醇成の観点より〜. 医療情報学 34(Suppl.). 2014: 356-357.

18）エーブ・ワグナー, デービッド・ワグナー。よりよい人間 関係とコミュニケーションスキル：TA+NLP. 東京：チー 厶医療，2000. 